\title{
The Benefits of Using Radiocarbon Dating and an Interdisciplinary Approach for Identifying Contamination of Archaeological Find Assemblages. A Case Study from the Multi-period Settlement Site at Rakovice, Czech Republic
}

\author{
Tereza Šálkováa,b,c*, Tomáš Hiltscher ${ }^{a}$, Dagmar Dreslerovád, Lenka Kovačikovác, Jaroslav Jiřík a,e \\ ${ }^{a}$ Prácheň Museum in Písek, Velké náměstí 114, Pisek, Czech Republic \\ ${ }^{b}$ Faculty of Arts, Institute of Archaeology, University of South Bohemia in České Budějovice, Branišovská 31 a, 37005 České Budějovice, Czech Republic \\ ${ }^{c}$ Faculty of Science, Laboratory of Archaeobotany and Palaeoecology, University of South Bohemia in České Budějovice, Branišovská 1760, \\ 37005 České Budějovice, Czech Republic \\ ${ }^{d}$ Institute of Archaeology of the Czech Academy of Sciences, Prague, Letenská 4, 11801 Praha 1, Czech Republic \\ ${ }^{e}$ Faculty of Arts, Institute for Archaeology, Charles University in Prague, Náméstí Jana Palacha 2, 11638 Prague 1, Czech Republic
}

\section{A RTICLE INFO}

\section{Article history}

Received: $2^{\text {nd }}$ April 2020

Accepted: $17^{\text {th }}$ June 2020

DOI: http://dx.doi.org/10.24916/iansa.2020.1.2

\section{Key words}

contamination

taphonomy

plant macroremains

Linum usitatissimum

radiocarbon dating

archaeology

\begin{abstract}
A B S TRACT
The contamination of archaeological find assemblages at multi-period (and other) sites can sometimes go undetected. In this article we seek to highlight this problem through analysis of the fill of settlement features from a site at Rakovice, South Bohemia, Czech Republic. After a detailed spatial evaluation of different categories of finds, an analysis of plant macroremains, and radiocarbon dating, what had originally appeared to be a clear-cut archaeological situation of the superposition of two features from the Roman and Early Mediaeval periods was shown to be much more complex. This discovery confirmed the value of a multi-disciplinary approach and especially of radiocarbon dating even in apparently simple contexts. What we are especially concerned about is the risk of assigning particular periods to multi-period sites that have been insufficiently radiocarbon dated.
\end{abstract}

\section{Introduction}

Earlier residuality and later intrusion in archaeological assemblages are key problems in settlement sites with a long history of human occupation. The spectra of artefact and ecofact assemblages in the features are often contaminated - at least partially - as a result of depositional or post-depositional processes (Borojevic, 2011; Kuna and Němcová, et al. 2012; Pelling et al., 2015; Peeling et al., 2015; Šálková et al., 2016). Our multi-disciplinary analysis of the assemblage of plant remains from the superposition of two features from the Early Roman and Early Mediaeval periods from the site at Rakovice, Czech Republic (Figure 1), demonstrates the importance of such analysis for recognizing contamination of the features' fills. An archaeological feature, severely damaged by ploughing, was found during a surface survey

*Corresponding author. E-mail: terezasalkova@seznam.cz in April 2015. The subsequent excavation revealed what appeared to be a simple stratigraphic scenario. A shallow, sunken, elongated feature 1 (hereafter referred to as $\mathrm{F}$ 1) was partially disrupted in its north-western part by another shallow oblong feature 1.1 (hereafter referred to as $\mathrm{F} 1.1$ ). Based on pottery finds, F 1 was dated to the beginning of the Early Roman period (several sherds also date to the La Tène period). The stratigraphically later $\mathrm{F} 1.1$ was dated to the Early Mediaeval period. However, during processing of the archaeobotanical finds, the formation of the fill of these two features began to raise questions. Especially dubious was a large quantity of charred flax seeds (Linum usitatissimum) recovered in similar quantities from both features. AMS radiocarbon data on the flax and other plant macroremains subsequently confirmed that the formation of the features' fills was more complex than it had appeared on the basis of the field observations and the typological analysis of the pottery fragments. 


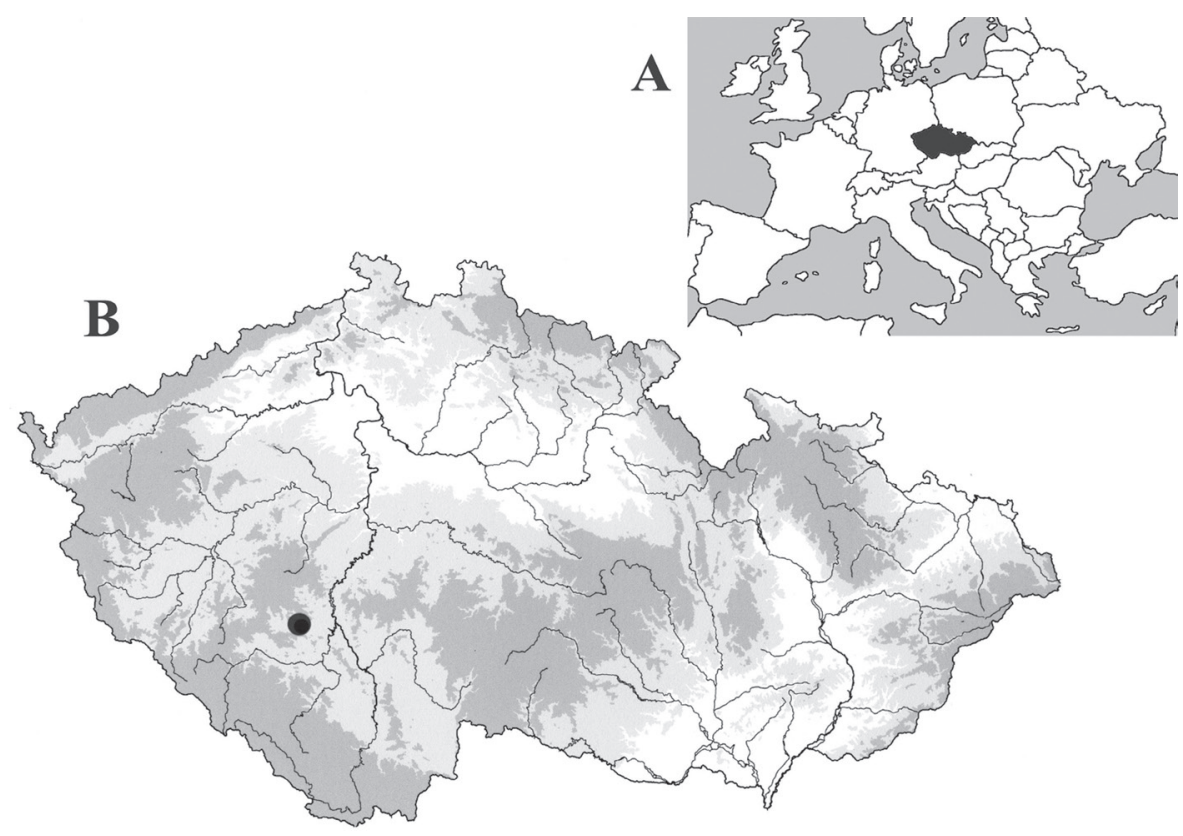

Figure 1. Position of the Rakovice site (marked by a dot) within the Czech Republic.

In this article we aim to demonstrate that: (a) the earlier residuality and later intrusion of plant remains can be crucial for archaeological interpretation even in a situation that appears stratigraphically clear and in which each archaeological feature comprises only artefacts (mostly ceramics) dated to specific periods; (b) the true formation history and "contamination" cannot be recognized without radiocarbon dating of several specimens and without detailed knowledge of the local archaeology and the spectrum of plants cultivated in a particular period. Our objective is to highlight the dangers of unrecognized contamination and the subsequent misinterpretation of archaeological contexts, and to suggest that such contamination can only be revealed by a multi-disciplinary approach and by including radiocarbon dating.

\section{Materials and methods}

\subsection{Background information}

The site under investigation is situated in the north-western part of the Písek region (South Bohemia, Figure 1), which was settled in the Upper Palaeolithic and Mesolithic, the Iron Age, the Early Roman period, and from the early Middle Ages until the present (Břicháček and Fröhlich, 1993; Dubský, 1925; Debnar, 2000; Dreslerová, 2004; Fröhlich et al., 2008; Hiltscher et al., 2018).

The soil horizon consists mainly of gleyic modal stagnosols generated on the polygenetic loam substrate and glacial sediments (Němeček and Lérová, 2009). The site is at $465 \mathrm{~m}$ asl. in the warmest part of South Bohemia, which is also, except for the region of the upper Vltava and Elbe lowlands, the warmest part of the whole of Bohemia (Quitt, 1971). Luzulo albidae-Quercetum petraeae and/or Abieti-Quercetum were reconstructed as the potential natural vegetation (Neuhäuslová et al., 1997).

\subsection{Archaeological excavation}

An excavation trench covering an area of $20 \mathrm{~m}^{2}$ was dug in the area with the highest accumulation of ploughedout pottery and divided into a network of $1 \mathrm{~m}$ squares (Figure 2). The fills of the sunken features were excavated in 10-cm-thick mechanical layers. F 1 (with a volume of approx. 17,000 1) was a flat, irregular, elongated pit, oriented north-south. The bottom was slightly concave. There was a concentration of stones at the southern end, under which a larger quantity of pottery fragments were excavated. The fill was dark brown: a black loamy deposit with a high content of a charcoal admixture. It contained fragments of pottery, animal bones, and a spindle whorl. F 1.1 (with a volume of approx. 6,700 1) was a shallow, oblong pit, oriented northeast-southwest, with a flat bottom and cutting into F 1 . The fill was dark brown: again, a black loamy deposit with a high content of a charcoal admixture. F 1.1 contained fragments of pottery, animal bones, and a glass bead.

A sample of sediment with a volume of 10-25 litres from each square and layer was processed by flotation in a flotation tank (modified ANAKARA type) using a $0.25 \mathrm{~mm}$ square mesh sieve for the floating of the organic component and a $0.5 \mathrm{~mm}$ sieve for the mineral component (Pearsall, 1989). Some 38 samples with a total volume of 516 litres were processed (325 litres from F 1; 105 litres from F 1.1; 86 litres from the boundary area between the two features). Archaeobotanical and archaeozoological material and fine artefacts from the flotation and heavy residue fractions were sorted and analysed further (for details, see Excavation report no. C-201901695; AMČR).

\subsection{Analysis of plant macroremains}

The samples were studied under a stereomicroscope. All botanical material was sorted, but only the charred plant macroremains were taxonomically determined and counted 

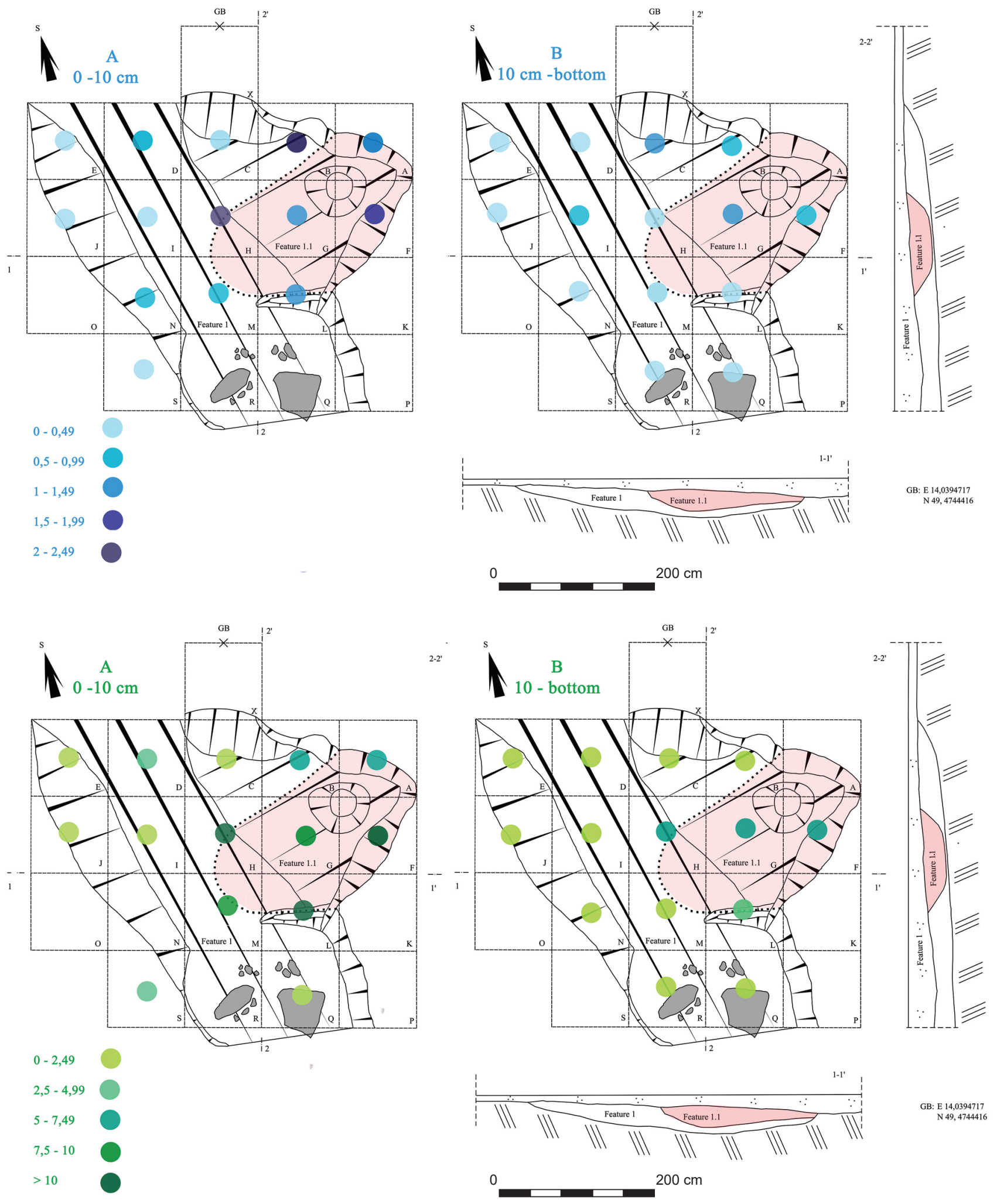

Figure 2. Concentration of plant macroremains in one litre of the fill in particular sectors: A (blue dots): density of flax seeds; B (green dots): density of macroremains without flax.

because in dry environments it is likely that non-charred plant remains are a modern intrusion. Seeds and fruits were classified according to reference collections and the literature
(Anderberg, 1994; Berggren, 1981; Cappers et al., 2006; Hajnalová, 1993; Hajnalová, 1999; Lhotská and Chrtková, 1978; Jacomet, 2006). 
Archaeological assemblages of crops from South Bohemia dated to the Early Roman period (Přeštovice, Rataje, Dolní Bukovsko; Śálková et al., 2014) and the Early Mediaeval period (Netolice, Nemětice, Počáply, Svákov u Soběslavi, Slavonice, Staré Prachatice; Chvojka et al., 2012; Parkman et al., 2015; Beneš et al., 2014; Opravil, 2000) were used as reference samples.

\subsubsection{Multivariate statistics of archaeobotanical data}

To detect and understand the patterning of the data from the site and in the regional context, archaeobotanical data were studied using multivariate statistical analysis performed in the Canoco v. 5 programme (ter Braak and Šmilauer, 2002). Detrended correspondence analysis (DCA) was carried out for data from the site. The maximum length of the gradient was 3.0. Logarithmic transformation of the data was used. The DCA was used to compare the regional context archaeobotanical data as the gradient length was 3.19. Percentages and logarithmic transformation were used to evaluate the regional data.

\subsection{Osteological analysis}

Archaeozoological material was obtained by both hand-retrieval and flotation. The analysis of this material serves as a referential method for the study of depositional and post-depositional processes. Bone concentration was the same in both features.

Taxonomically determined animal bones and teeth were quantified as NISP (Number of Identified Specimen). The age of cattle was estimated according to the phase of eruption, replacement (Higham, 1967) and the wear stage of teeth (Legge, 1992). When identifying the slaughter age of domestic pigs, the tooth replacement and the stage of crown wear was observed (Grant, 1982). The age of sheep and goat was determined on the basis of abrasion indexes for molars (Helmer and Vigne, 2004).

\subsection{Radiocarbon dating}

To secure the representative taxa for archaeologicallydetected periods, radiocarbon dating of ten samples of charred flax seeds, and the caryopses of common wheat (Triticum aestivum), einkorn (Triticum monococcum), barley (Hordeum vulgare) and corn-cockle (Agrostemma githago) were performed in two sets of AMS measurements: the first in the laboratory of the University of Georgia (UGAMS); the second set of graphites was prepared in the Czech Radiocarbon Laboratory (CRL) (Table 1, Figure 3) and the measurements were taken at the MICADAS facility in the Hertelendi Laboratory of Environmental Studies (DebA), ATOMKI HAS, in Debrecen, Hungary. Calibrations were performed in OxCal, version 4.3. (Reimer et al., 2013). Animal bones from the site did not contain a sufficient amount of collagen to enable dating.

\section{Results}

\subsection{Artefacts}

A total of 797 fragments of pottery and 35 daub fragments were collected from the topsoil and excavation trench. Some 566 fragments of pottery from $\mathrm{F} 1$ were dated to the beginning of the Early Roman period (35 BC-180/200 AD) (Droberjar, 2008), and one fragment to the La Tène period (400-25 BC). From F 1.1, 64 fragments were dated to the Early Mediaeval period, specifically to the so-called Middle Hillfort period (800/850-950 AD) (Parkman, 2003; Lutovský, 2011). No artefacts from other periods were found in the features.

\subsection{Plant macroremains}

We obtained 2,617 finds of charred macroremains (1,225 from F 1; 698 from F 1.1; 694 from the boundary area between the two features). Taxa composition varied in the two features. The trends are similar (Figure 4a, 4b) but the average density of plant macroremains in one litre of deposit differ considerably, with $2.5 \mathrm{PR} / \mathrm{l}$ (plant remains per litre) in F 1 and $12.6 \mathrm{PR} / 1$ in F 1.1 (for more detail, see Figure 2). Cereal remains dominate in both features (F1 - 38\%; F $1.155 \%$ ). The remains of weeds and ruderals are subdominant (F $134 \%$; F $1.123 \%$ ). The remains of oil crops, e.g. flax seeds, were numerous (F1 19\%;

Table 1. AMS radiocarbon dates. Data were calibrated by OxCal v4.2.4 (Bronk Ramsey, 2013) and IntCal13 (Reimer et al., 2013).

\begin{tabular}{|c|c|c|c|c|c|c|c|c|c|}
\hline Code & Sample & Feature & Sector & $\begin{array}{c}\text { Mechanical } \\
\text { lyer }\end{array}$ & Taxa & $\begin{array}{l}\text { Predicted dating } \\
\text { based on artifacts }\end{array}$ & Bp & \pm & $\begin{array}{c}\text { Calibrated date } \\
(95,4 \%)\end{array}$ \\
\hline UGAMS23270 & 401 & 1 & I & 10-bottom & Linum usitatissimum & Roman period & 1120 & 20 & $887-981 \mathrm{AD}$ \\
\hline UGAMS23271 & 406 & 01.I & $\mathrm{L}$ & $0-10 \mathrm{~cm}$ & Linum usitatissimum & Early Middle ages & 1070 & 25 & $897-1020 \mathrm{AD}$ \\
\hline $17 \_510$ & 415 & 1 & $\mathrm{R}$ & 20-bottom & Triticum aestivum & Roman period & 1221 & 20 & $712-885 \mathrm{AD}$ \\
\hline $17 \_511$ & 424 & 01.I & $\mathrm{F}$ & 10-bottom & Agrostemma githago & Early Middle ages & 1205 & 23 & $727-888$ AD \\
\hline $19 \_103$ & 407 & 1 & I & $0-10$ & Linum usitatissimum & Roman period & 1121 & 21 & $886-983$ AD \\
\hline 19_104 & 410 & 01.I & $\mathrm{L}$ & $0-10$ & Linum usitatissimum & Early Middle ages & 1116 & 22 & $888-984$ AD \\
\hline 19_105 & 434 & 1 & $\mathrm{R}$ & $10-20 \mathrm{~cm}$ & Triticum monoccocum & Roman period & 2032 & 23 & $108 \mathrm{BC}-28 \mathrm{AD}$ \\
\hline $19 \_106$ & 414 & 01.I & $\mathrm{G}$ & $0-10$ & Linum usitatissimum & Early Middle ages & 1113 & 21 & $890-984$ AD \\
\hline $19 \_107$ & 428 & 1 & $\mathrm{~S}$ & 0-bottom & Linum usitatissimum & Roman period & 1078 & 21 & $898-1017$ AD \\
\hline $18 \_071$ & 410 & 01.I & $\mathrm{L}$ & $0-10$ & Hordeum vulgare & Early Middle ages & 1186 & 20 & $773-889 \mathrm{AD}$ \\
\hline- & - & 01.I & $\mathrm{F}$ & $0-10$ & Bos taurus & Early Middle ages & - & - & - \\
\hline
\end{tabular}


Figure 3. Group diagram comparing the dating of samples. Green: interval of the ERP pottery typological dating; red: interval of the EMP (so-called Middle Hillfort period) pottery typological dating. Calibration according to Reimer et al. (2013).

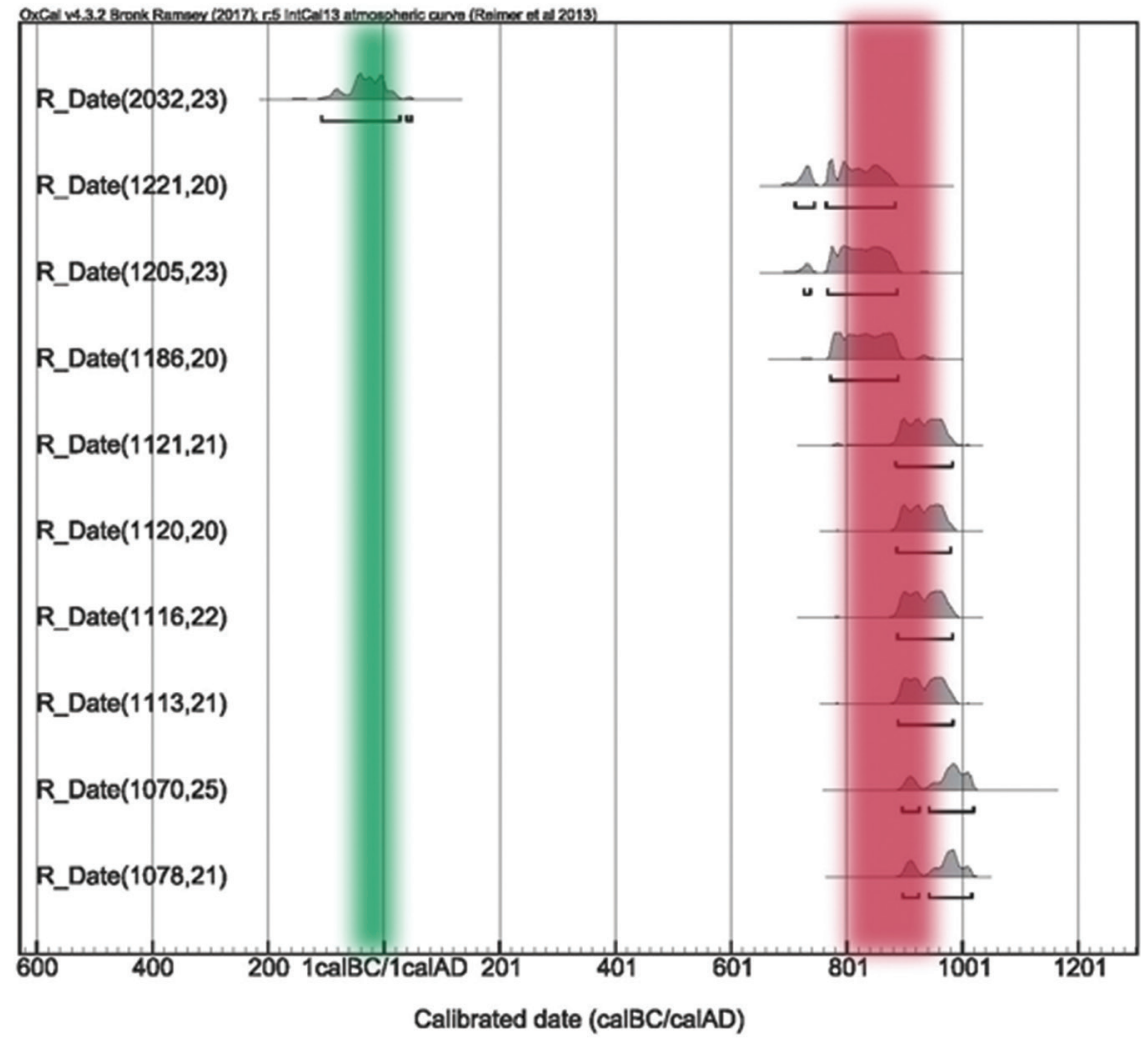

F $1.111 \%$ ); legumes were rather scarce in both features. Seeds and fruits of species found in woodland and at woodland edges which might have been collected and used for various purposes are also scarce but regularly occur in many samples (F1 4\%; F 1.1 6\%). Plants typical of wet meadows were found in similar quantities ( $4 \%$ in both features; Figure $4 a)$. Common millet (Panicum miliaceum) was the dominant cereal crop in both assemblages. Barley (Hordeum vulgare) and common wheat (Triticum aestivum) were subdominants.

Cereals belonging to a group of staples typical of earlier prehistoric agriculture, such as einkorn (Triticum monococcum; F 1.1), emmer (Triticum dicoccum; F 1) and spelt (Triticum spelta; F 1 and F 1.1), were found in the assemblages in small quantities.

Both assemblages also contained small quantities of "progressive" cereals such as oats (Avena cf. sativa) and rye (Secale sereale) (Figure 4b).

Only a few legume seeds were found: lentil (Lens culinaris) in F 1 and lentil and peas (Pisum sativum) in F 1.1. Large numbers of seeds (and a small number of capsules) of common flax (Linum usitatissimum) were found in both features (Figure 2a).

Both features contained macroremains of potentially useful plants which probably originated in woodland or at
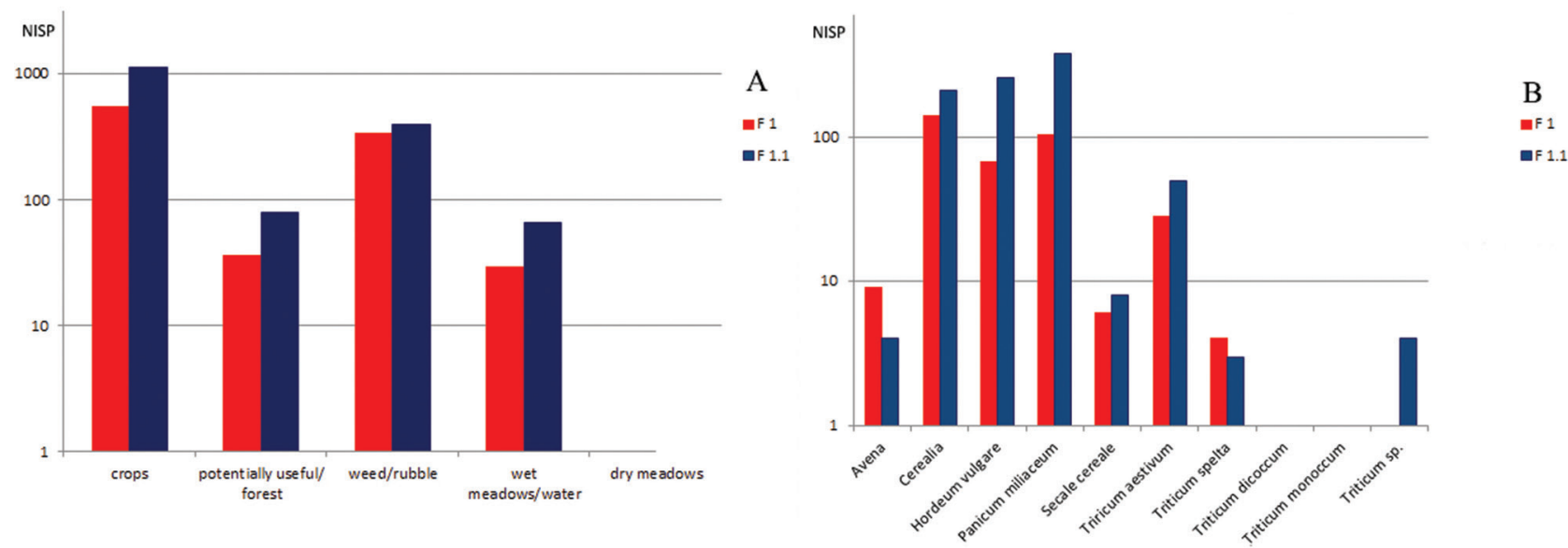

Figure 4. A - Reconstruction of spectra of plants from different ecological groups in F 1 and F 1.1 (logarithmic scale); B - Spectra of cereal remains in F 1 and F 1.1 (logarithmic scale). 
woodland edges, such as Rubus ideaus, Rubus fruticosus, Corylus avellana, Fragaria/Potentilla. Luzula luzuloides seeds in F 1 also suggest a woodland environment. An achene of Fragaria vesca, and a fragment of a Prunus sp. stone were found in F 1 , and stones of Prunus domestica subsp. insititia in F 1.1. Both features contained finds of achenes of Sambucus nigra, and in F 1 also those of S. ebulus and $S$. racemosa.

Both features yielded a wide spectrum of plant remains typical of fields and scrubland. Galium spurium and Chenopodium album were the most abundant. Vicia tetrasperma, Galium aparine, Agrostemma githago, Setaria sp., Polygonum aviculare and Fallopia convolvulus were often found in large quantities in both features. A wide range of taxa were found in both features, but from each taxa only a few macroremains, namely: Vicia sp., Atriplex sp., Silene alba, Centaurea cf. cyanus, Chenopodium ficifolium, and Viola sp. Veronica hederifolia, Chenopodium hybridum, Medicago lupulina, Scleranthus annuus and Setaria pumila appeared only in F 1, as did Bromus sp., Fumaria officinalis, and Polycnemum arvense.

Plant remains typical of wet meadows included Phleum pratense, Alopecurus pratense and Juncus sp. Small quantities of Carex sp., Trifolium, Trifolium/Medicago, Trifolium pratense, Persicaria lapathifolia and Plantago lanceolata were found in both features. Lychnis flos-cuculi was found only in F 1.1; Myosotis sp., Ranunculus flammula and the aquatic plant Potamogeton only in F 1. On the other hand, Acinos arvensis, whose seeds were found in small numbers in both features, is typical of drier habitats.

The collections are similar regarding both the species and the reconstruction of the original plant biotopes (Figure $4 \mathrm{~b}$ ). However, multivariate statistical analysis showed that the samples from the two features differ in their composition of characteristic botanical taxa (Figure 5).

\subsubsection{Reference assemblages}

The Early Mediaeval period (hereafter referred to as the EMP) reference assemblage from South Bohemia comprises
6,984 remains of cultural plants from six sites; the Early Roman period (hereafter referred to as the ERP) assemblage comprises 229 remains of crops from three sites.

The same taxa are present in both periods but in different proportions (Figure 6). The main difference is in the presence or quantity of glume wheats such as emmer, spelt and einkorn. While in the ERP samples these usually comprise over 20\%, in EMP samples, if present at all, they rarely reach $1 \%$ (and these may be undetected residuals/contaminants). The ERP samples are usually dominated by free-threshing wheat or barley; in the EMP there is either free-threshing wheat or wheat in combination with millet. Rye and oat are more numerous in the EMP than in the ERP. The samples from both periods from Rakovice (RF 1 and RF 1.1) not only differ from the reference collections but are strongly similar to each other with respect to the dominant combination of millet and barley (and free-threshing wheat). They differ in the amount of glume wheats, but the ERP did not reach the expected rate of $20 \%$.

Detrended correspondence analysis (DCA) supports the results of the simple statistics (Figure 6) for the evaluation of the site in the context of the referential assemblages. It shows that the taxonomic composition and ubiquities of individual taxa in the Rakovice samples differ from those of EMP and ERP assemblages (Figure 5), but also that the composition of the taxa from the two features at Rakovice is almost identical (Figure 8). The major difference from other samples is the high proportion of millet and barley in both features.

\subsection{Osteological analysis}

Osteological material consisted of 880 finds whose average concentration was similar in F 1 and F 1.1, with 0.03 bones per litre of deposit. Some 432 animal bones were burnt at high temperatures.

F 1 contained 496 osteological finds but only 45 were taxonomically determined. Most of the finds from $\mathrm{F}$ 1, $73.3 \%$ NISP, belonged to Suinae (Sus sp.); a smaller number, 22.2\% NISP, were Bovinae (Bos sp.). Although the wild and domesticated animals is not easily distinguished, we suppose

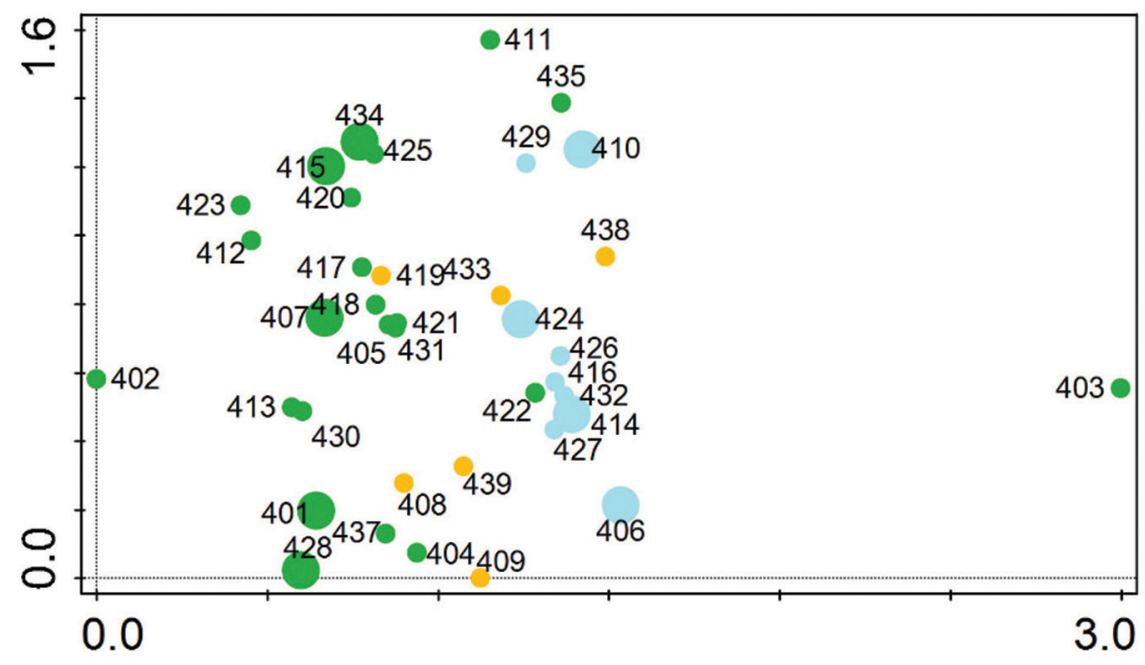

Figure 5. Detrended correspondence analysis (DCA). Green: samples from F 1; blue: samples from F 1.1; yellow: samples from boundary area between the two features. First axis explains $17.78 \%$ variability; the first and the second axis together $24.24 \%$. 
Figure 6. Reference assemblages of crop remains from the Early Roman and Early Mediaeval periods of South Bohemia. Left: EMP. RF1.1 = Rakovice F 1.1; SSL = Soběslav-Svákov; POC $=$ Počáply; HUN = Hradec u Nemějic; SPR = Staré Prachatice; NET $=$ Netolice; SLA $=$ Slavonice Right: ERP. RF1 = Rakovice F 1; DBO = Dolní Bukovsko; RAT = Rataje; PRE = Přšst'ovice. TA = Triticum aestivum; TAC = Triticum compactum $; \mathrm{PM}=$ Panicum miliaceum $; \mathrm{HV}=$ Hordeum vulgare $; \mathrm{SC}=$ Secale cereale; $\mathrm{AV}=$ Avena sativa $; \mathrm{TD}=$ Triticum dicoccum; TS = Triticum spelta; $\mathrm{TM}=$ Triticum monococcum

\section{Cereals}

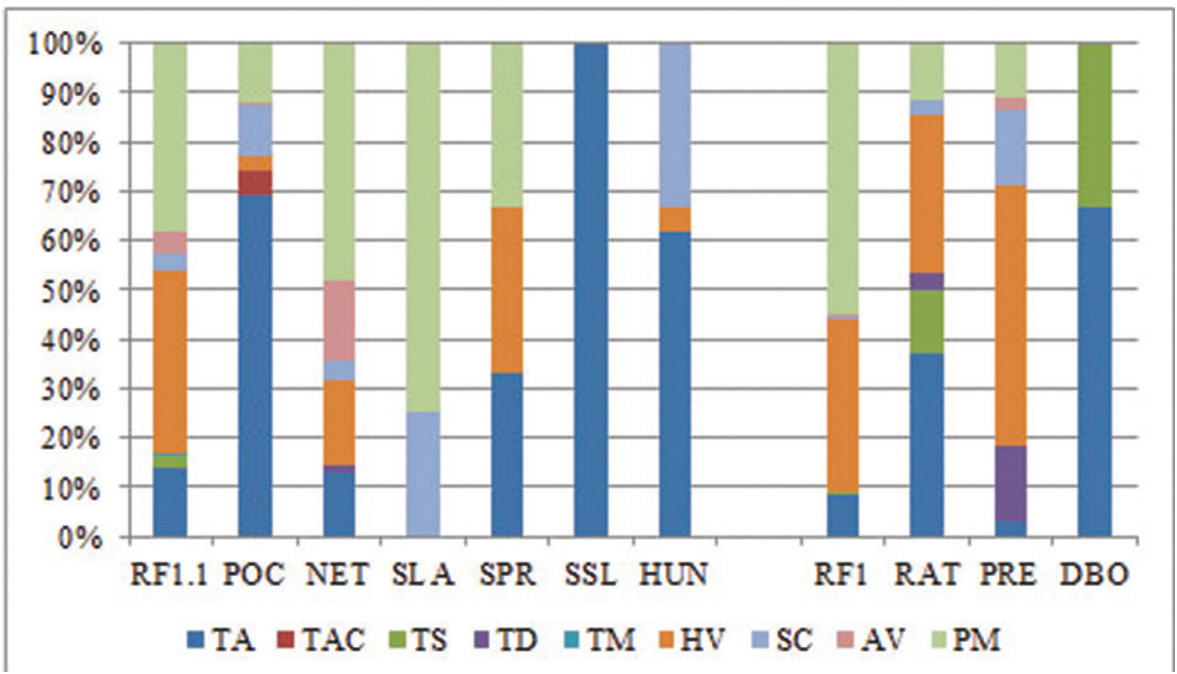

that the $3^{\text {rd }}$ upper molar of pig belonged to a domesticated specimen slaughtered at the age between 16 and 20 months. Cattle (Bos taurus) is documented by a fragment of a metatarsal bone and three molars, one of which belonged to a young individual and the second to a 7- or 8-year-old animal. One molar documents the occurrence of a subadult sheep or goat (Ovis/Capra). Among the finds of smaller mammals are the bone remains of a vole (Microtus sp.). The assemblage also contained two eggshell fragments of bird.

F 1.1 contained 173 bones and teeth, of which only 5.2\% were identified, including cattle, sheep or goat aged 4-6 years, and a vole. There were also bird bones (at the size of a chicken).

From the boundary area between the two features, 221 fragments of bones and teeth were recovered, of which

Figure 7. Contexts of the radiocarbondated samples. Blue dots: $0-10 \mathrm{~cm}$; red dots: $10 \mathrm{~cm}$-bottom. AMS date assigned to: yellow centre: Late La Tène, early RP; brown centre: Middle Hillfort period; green centre: later phase of Middle Hillfort period to earlier phase of Late Hillfort period (all flax seeds).

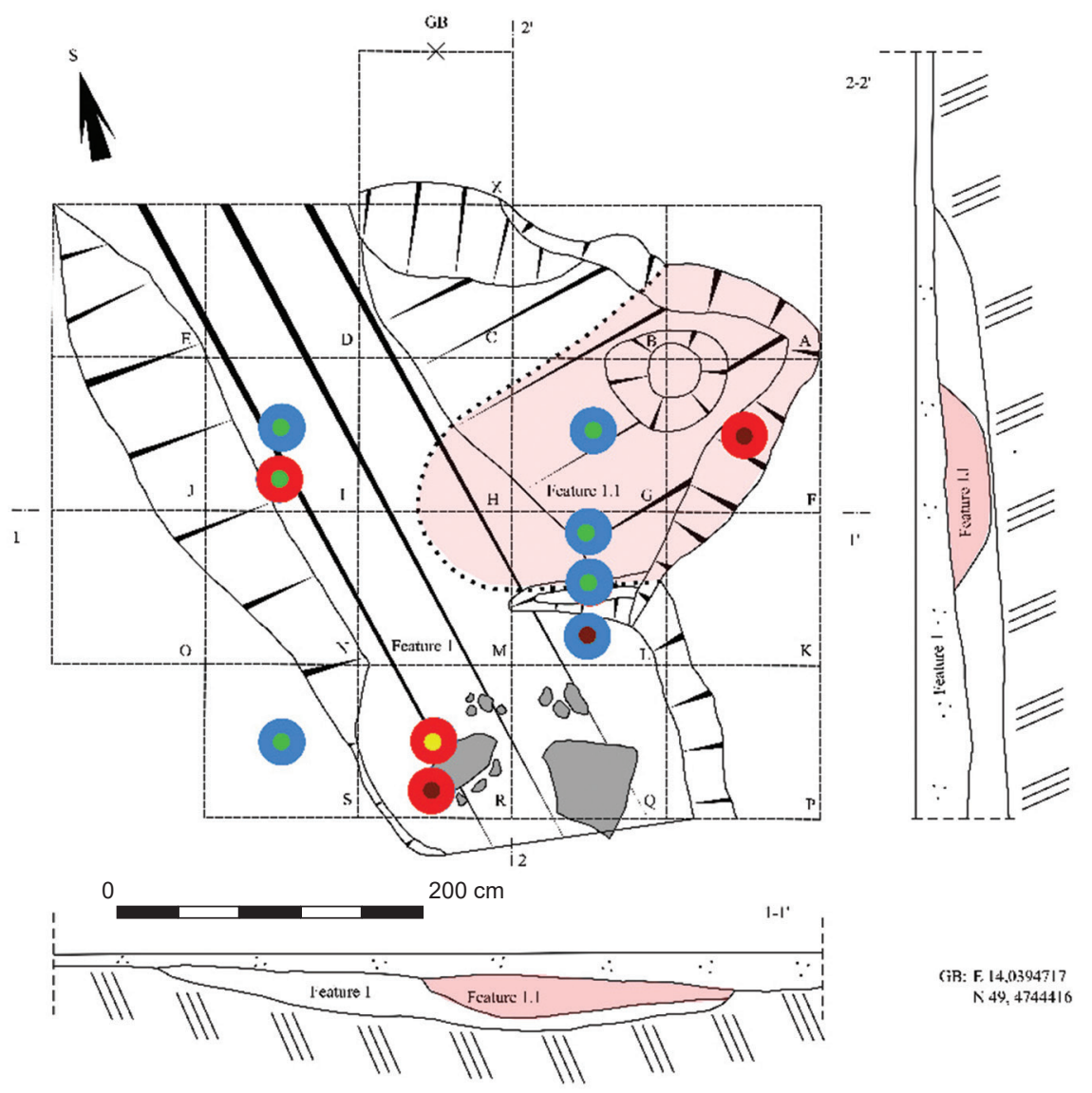


$7.6 \%$ were identified. The bones of cattle, pig, and mouseor vole-like rodents (probably a common vole, Microtus arvalis) were determined. A recent origin for the rodents cannot be excluded. The vertebra of a lizard (Lacertidae) and a small fish were also present.

\subsection{Radiocarbon dating}

The common flax seeds from both features were dated between 1070 and $1121 \pm 20-25$ BP. The corn cockle from F 1.1 was dated to $1205 \pm 23 \mathrm{BP}$; the naked wheat caryopsis from $\mathrm{F} 1$ to $1221 \pm 20 \mathrm{BP}$; the barley caryopsis from $\mathrm{F} 1.1$ to $1186 \pm 20$ BP (Table 1, Figures 3, 7). Calibrated data show three dating intervals. The caryopsis of einkorn found in F 1 was dated to $1032 \pm 23 \mathrm{BP}$. It corresponds to the ERP pottery and to an older residuum of the final phase of the La Tène period. Macroremains falling into the earlier EMP and flax seeds from the later part of the EMP horizon were present in both features.

\section{Discussion and interpretation}

\subsection{Dating alternatives}

Our research detected part of a settlement area that was repeatedly used in late prehistory and the EMP. Long-term exploitation of the area meant the fill of the two features comprised earlier residuals and later intrusions.

With respect to artefact analysis, the dating of the features was straightforward. The stratigraphically earlier $\mathrm{F} 1$ comprised finds from the ERP, with an insignificant pottery

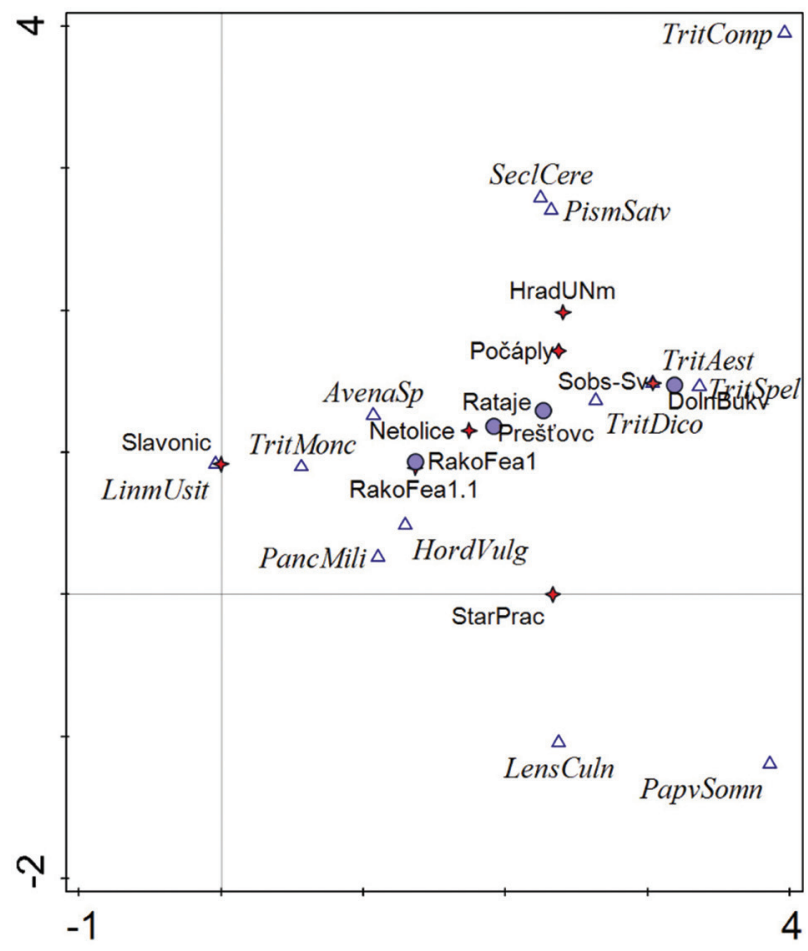

Figure 8. Detrended correspondence analysis (DCA). Blue dots: early RP; red star: EMP. First axis explains $30.53 \%$ variability; the first and the second axis together $49.46 \%$. admixture from the (late) La Tène period; the later F 1.1 comprised pottery classified clearly into the EMP.

The archaeozoological analysis showed differences in the spectrum of taxa in both features, but the number of determined finds was too low to draw wider archaeological conclusions.

The plant macroremains differed slightly in taxa and density, but it seems that at present the spectrum of crops from the ERP and EMP in South Bohemia is not chronologically sensitive enough (Figure 8). To assign two assemblages of plant macroremains to archaeological periods simply on the basis of their plant spectra and taxa ratio is highly problematic.

Radiocarbon dating showed that the plant macroremains in F 1 originated from at least three different periods: the Late La Tène period or ERP; the earlier part of the EMP (Early to Middle Hillfort period); and the later part of the EMP (Middle to Late Hillfort period). This is partly in agreement with the relative dating of the artefacts. The plant remains in F 1.1 originated in the two periods or phases of the EMP. It is also clear that the intervals of the earlier and later EMP data do not overlap and therefore represent two different phases of occupation of the site.

The chronology of the artefacts of the Late La Tène and ERP at Rakovice is more sensitive than the interval of the absolute data obtained by the radiocarbon analysis. It is not possible, therefore, to assign this radiocarbon date to either of these periods. In the case of the EMP, the result is the opposite. The sensitivity of the typological chronology of pottery from this period is low (Lutovský, 1998). It is not possible, therefore, to say whether the artefacts come from the earlier or later EMP phase or indeed from both (Figure 9). The first possibility can be supported by the occurrence of two archaic-looking fragments of the upper parts of vessels. A decoration of random, narrow, vertical cuts was also registered on a pot discovered at a nearby burial mound at Kožlí near Orlík nad Vltavou, which was radiocarbon dated to 632-764 cal AD (Lutovský, 1996, 47 ). Finds of such an age were previously unknown in the Rakovice microregion.

\subsection{Formation of the fills of $F \mathbf{1}$ and $F \mathbf{1 . 1}$}

The presence of relatively high concentrations of common flax seeds in both features is crucial for the interpretation of the formation of their fill. In previous studies, flax has not been documented in the RP in South Bohemia and all dated flax seeds selected from both features and from the boundary area between them are from the later EMP. Flax seeds contain a large amount of oil and during carbonization often burn without leaving macroscopic evidence (e.g. Kočár and Dreslerová, 2010). Carbonized seeds are fragile and prone to breaking or being totally destroyed. As the preservation of the Rakovice flax seed is good, the carbonization must have happened at low temperatures and in the partial absence of air (Märkle and Rösch, 2008). Furthermore, preand post-depositional processes caused little destruction to the seeds, which could suggest that the period between 

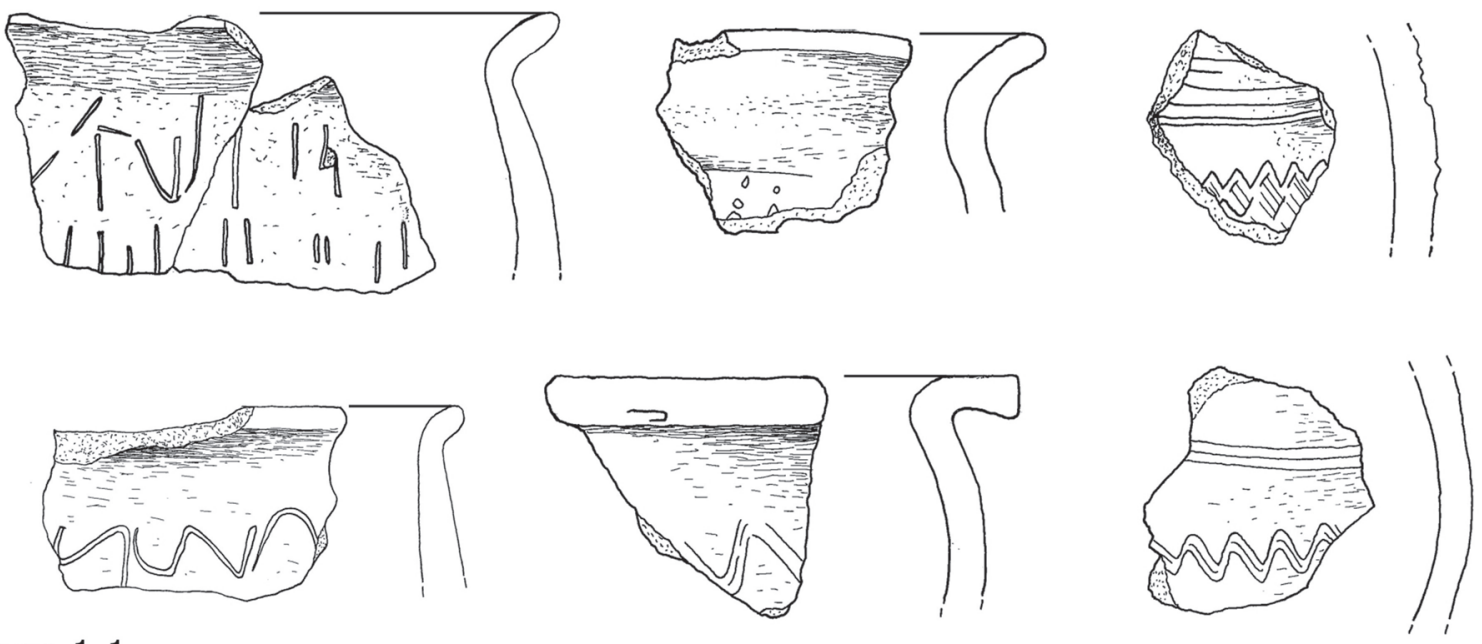

feature 1.1
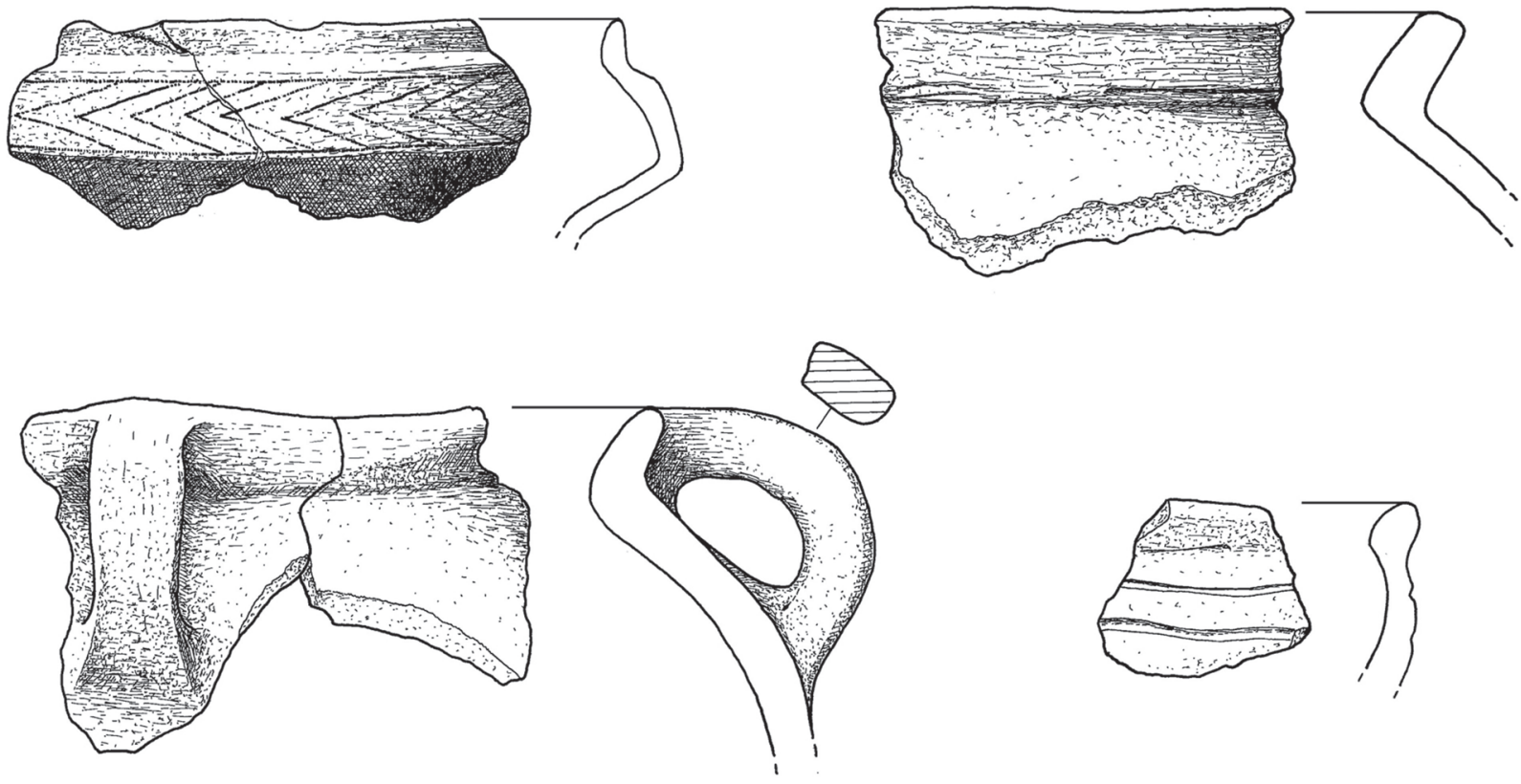

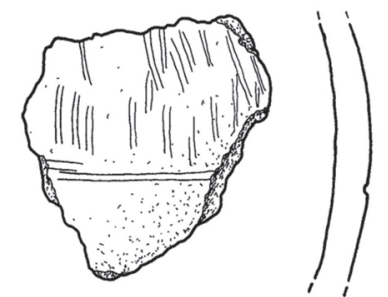

feature 1
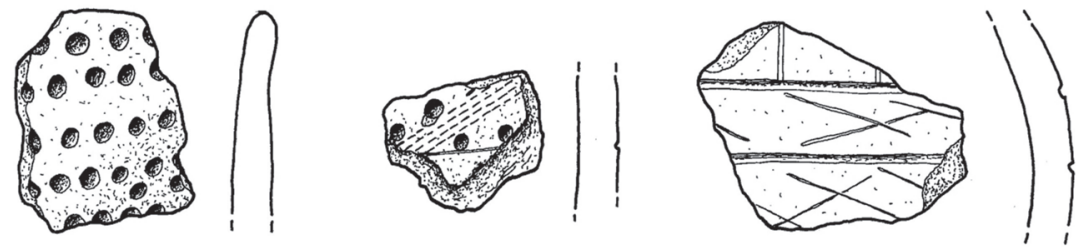

0 $5 \mathrm{~cm}$

Figure 9. Examples of pottery fragments from F 1.1. (EMP) and F 1 (ERP).

their carbonization and deposition was relatively short and probably reflects a single event. Flax seeds were distributed throughout the fill of the two features, but their concentration in F 1.1 was significantly higher than in F 1 (Figure 2).
Bioturbation as a source of contamination of the two features by flax seeds can be ruled out because of the absence of a higher concentration of seeds in the overlying horizons of $\mathrm{F} 1$ and $\mathrm{F} 1.1$, and because of the highly regular distribution of 
the seeds throughout the fill: contamination by bioturbation usually results in concentrations of remains in small areas represented by, for example, animal burrows or tunnels.

The most likely scenario is that both features and their fills formed in the later EMP. This means the fill of $\mathrm{F} 1$ represents a sediment comprising pottery and archaeobotanical finds redeposited in the pit from an unknown Roman period feature or features, or a settlement layer situated somewhere within the multi-period settlement which was enriched by earlier EMP deposits or waste used to fill up the later EMP feature. Sometime either before or during the deposition of the fill, the organic material containing charred flax seeds was admixed. In this scenario, F 1.1 would represent not a separate sunken feature but a stratigraphic unit of F 1 .

Alternatively, F 1.1 could have been dug out and filled shortly after the filling of F 1 . The three dated plant macroremains (barley, naked wheat, corn cockle) found in both fills could represent residue from a former field or other harvested area, or another unknown feature or settlement layer from the earlier EMP phase.

The third possible solution suggests that $F 1$ originated in the Roman period and F 1.1. in the earlier phase of the EMP. Activity connected with the processing of flax would take place here in the later phase of the EMP. Carbonized waste from this production would then enter the fills of both features by some unknown and undetermined process (such as the digging and slight mixing of sediments).

\subsection{Identifying the contamination of archaeological contexts}

Based on our findings we propose that when dealing with the taphonomy of any archaeological situation, complex or otherwise, the following steps should be taken:

(i) Remove all material systematically according to a predetermined sampling method, such as using a regular sampling grid within each mechanical layer of a particular thickness, or within the context. More than one type of analysis should be carried out and the results compared. The quantity of finds in particular contexts should be transferred into the same units so the contexts can be compared directly (e.g. density of finds as an average number of finds per one litre of sediment/deposit). The results should be interpreted in the context of the overall research.

(ii) Compare the results from each type of analysis with the (well-known) regional data.

(iii) Perform radiocarbon dating of organic finds even if the contexts seem to be clearly dated on the basis of typology, stratigraphy, or other types of dating.

(iv) Carry out a multidimensional analysis of the data.

\section{Conclusion}

A detailed archaeo-environmental analysis of a seeminglysimple find situation revealed the hidden danger of unrecognized depositional processes. We have shown that it can be misleading to "transfer" dating based on the typology of artefacts directly to other types of materials in the same context. Each category of material should be studied on its own.

Detailed and systematic sampling and flotation of the archaeological deposits that formed the fill of both features uncovered evidence that proved crucial for the archaeological interpretation. The fills do not represent closed find assemblages representing a single event, and their formation was strongly influenced by depositional or pre- or post-depositional processes. Radiocarbon data show that the plant macroremains are from more time periods than was documented by artefact typology.

The plant macroremains from F 1.1 could be (with reservation) assigned to a wider time interval of the EMP. The plant macroremains recovered from $\mathrm{F} 1$ are not suitable for reconstruction of the palaeoeconomy and the environment of the ERP (unless all species are dated and assigned to that period). To avoid introducing a bias, they should be excluded from studies when regional analysis and reference material of the period is required. It is also possible that our reference assemblages are affected by a similar error (especially the presence of glume wheats in the EMA), as would have happened in the Rakovice assemblages without careful analysis and radiocarbon dating.

There is no doubt that human activity took place at the site in question across four different periods: The La Tène and Roman periods, and the earlier and later phase of the Early Mediaeval period. One of the occupation phases of the EMA was recorded only in organic remains and from their radiocarbon dating. The exact nature of the human activity remains unclear.

\section{Acknowledgements}

This work was supported by the by OP RDE, MEYS, under the project "Ultra-trace isotope research in social and environmental studies using accelerator mass spectrometry", "Reg. No. CZ.02.1.01/0.0/0.0/16_019/0000728".

\section{References}

ANDERBERG, A., 1994. Atlas of Seeds and Small Fruits of NorthwestEuropean Plant Species with Morphological Descriptions. Part 4 Resedaceae - Umbeliferae. Stockholm: Swedish Museum of Natural History.

BERGGREN, G., 1981. Atlas of Seeds and Small Fruits of NorthwestEuropean Plant Species with Morphological Descriptions. Part 3 Salicaceae - Cruciferae. Stockholm: Swedish Museum of Natural History.

BRONK RAMSEY, C., 2013. OxCal 4.2.1. http://c14.arch.ox.ac.uk/oxcal/ OxCal.html.

BŘICHÁČEK, P., FRÖHLICH, J., 1993. Sídliště z doby rrímské v Probulově (okr. Písek). Archeologické výzkumy v jižních Čechách, 8, 67-74.

BOROJEVIC, K., 2011. Interpreting, dating, and re-evaluating the botanical assemblage from tell Kedesh: A case study of historical contamination. Journal of Archaeological Science, 38, 829-842.

CAPPERS, R., BEKKER, R., JANS, J., 2006. Digitale Zadenatlas van Nederland [Digital seed atlas of The Netherlands]. Groningen: Barkhuis 
Publishing and Groningen University Library.

DEBNAR, A., 2000. Rakovice okr. Písek. Výzkumy v Čechách, 1998, 185.

DRESLEROVÁ, D., 2004. Povrchové sběry na severním Prácheňsku v letech 2001-2003. Výzkumy v Čechách, 2002, 369-416.

DROBERJAR, E., 2008. K chronologii nejstarších labskogermánských (svébských) sídlišt' v Čechách. In: E. Droberjar, B. Komoróczy, D. Vachůtová, eds. Barbarská sídliště, chronologické, ekonomické a historické aspekty jejich vývoje ve světle nových archeologických výzkumü. Brno, pp. 99-110.

DUBSKÝ, B., 1925. Laténsko-ř́mské sídliště u Zalužan na Mirovicku. Památky archeologické, 34, 445-446.

FRÖHLICH, J., JIŘíK, J., LUTOVSKÝ, M., 2008. Raně středověké osídlení podél středního toku Vltavy. Archeologické výzkumy v jižnich Čechách, 21, 219-246.

GRANT, A., 1982. The use of tooth wear as a guide to the age of domestic ungulates. In: B. Wilson, C. Grigson, S. Payne, eds. Ageing and Sexing Animal Bones from Archaeological Sites. British Archaeological Reports, British Series, 109, pp. 91-108.

HAJNALOVÁ, E., 1993. Obilie $v$ archeobotanických nálezoch na Slovensku. Nitra: Archeologický ústav Slovenskej akadémie vied.

HAJNALOVÁ, E., 1999. Archeobotanika pestovaných rastlin. Nitra: Slovenská pol'nohospodárska universita $\mathrm{v}$ Nitre.

HELMER, D., VIGNE, J., 2004. La gestion des cheptels de caprinés au Néolithique dans le midi de la France. In: P. Bodu, C. Konstantin, eds. Approches fonctionnelles en Préhistoire. Actes XXVe Congrès Préhistorique de France Nanterre, 24-26 novembre 2000. Société Préhistorique Française Édition. Paris, pp. 397-407.

HIGHAM, C., 1967. Stock rearing as a cultural factor in prehistoric Europe. Proceedings of the Prehistoric Society, 33, 84-106.

HILTSCHER, T., MAŠKOVÁ, H., JIŘÍK, J., 2018. Nové poznatky $\mathrm{k}$ raně středověkému osídlení v povodí toku Skalice - povrchové sběry A. Debnara. Prácheňské muzeum v Písku v roce 2017, 36-90.

CHVOJKA, O., LUTOVSKÝ, M., JOHN, J., MENŠÍK, P., ŠÁLKOVÁ, T., THOMOVÁ, Z., 2012. Hradiště Svákov u Soběslavi. Archeologické výzkumy v jižnich Čechách, 25, 133-164.

JACOMET, S., 2006. Identification of Cereal Remains from Archaeological Sites, 2nd ed. Basel: IPNA Universität Basel.

KOČÁR, P., DRESLEROVÁ, D., 2010. Archeobotanické nálezy pěstovaných rostlin v pravěku České republiky [Archaeobotanical finds of cultivated plants in the prehistory of the Czech Republic]. Památky archeologické, 101, 203-242.

KUNA, M., NĚMCOVÁ, A., et al., 2012. Výpovéd' sídlištního odpadu [The evidence of settlement waste]. Praha: Archeologický ústav AV ČR, Praha.

LEGGE, A., 1992. Excavations at Grimes Graves, Norfolk 1972-1976. Fascicule 4: Animals, Environment and the Bronze Age Economy. London: British Museum Press.

LHOTSKÁ, M., CHRTKOVÁ, A., 1978. Karpologie a diasporologie československých zástupců čeledi Fabaceae. Praha: Academia.

LUTOVSKÝ, M., 1998. Mohylové pohřebiště v Kožlí u Orlíka, okr. Písek. K poznání raně středověkých mohyl ve středním Povltaví. Archeologie ve střednich Čechách, 2, 277-327.
LUTOVSKÝ, M., 2011. Jižni Čechy v raném středověku. Slovanské osidlení mezi Práchni a Chýnovem. České Budějovice: Veduta.

MÄRKLE, T., RÖSCH, M., 2008. Experiments on the effects of carbonization on some cultivated plant seeds. Veget Hist Archaeobot, 17 , 257-263. https://doi.org/10.1007/s00334-008-0165-7

MĚŘÍNSKÝ, Z., 2009. České země od př́chodu Slovanů po Velkou Moravu I., Praha: Libri.

NĚMEČEK, J., LÉROVÁ, Z., 2009. Klasifikace půdnich typů podle TKSP a WRB, Praha. http://geoportal.gov.cz.

NEUHÄUSLOVÁ, Z., MORAVEC, J., CHYTRÝ, M., SÁDLO, J., RYBNÍČEK, K., KOLBEK, J., JIRÁSEK, J., 1997. Mapa potenciálni prírozené vegetace České republiky 1: 500 000. Průhonice: Botanický ústav AV ČR

OPRAVIL, E., 2000. Archeobotanické nálezy z Hradce u Němětic. In: J. Michálek, M. Lutovský, eds. Hradec u Němětic: Sidlo halštatské a raně středovéké nobility $v$ česko-bavorském kontaktním prostoru. Strakonice, Praha, pp. 267-270.

PARKMAN, M., 2003. Osídlení Prachaticka v raném středověku. Archeologické výzkumy v jižnich Čechách, 16, 129-194.

PARKMAN, M., ŠÁLKOVÁ, T., BENEŠ, J., 2015. Raně středověký sídlištní objekt ze Starých Prachatic. Př́spěvek k paleoekonomii a absolutnímu datování osídlení. Archeologické výzkumy v jižních Čechách, 28, 187-200.

PEARSALL, S., 1989. Palaeoethnobotany: A Handbook of Procedures. San Diego: Academic Press.

PELLING, R., CAMPBELL, G., CARRUTHERS, W., HUNTE, K., MARSHALL, P., 2015. Exploring contamination (intrusion and residuality) in the archaeobotanical record: Case studies from central and southern England. Vegetation History and Archaeobotany, 24, 85-99.

QUITT, E., 1971. Klimatické oblasti Československa. Brno: Geografický ústav ČSAV.

REIMER, P., BARD, E., BAYLISS, A., BECK, J., BLACKWELL, P., BRONK RAMSEY, C., BUCK, C., CHENG, H., EDWARDS, R., FRIEDRICH, M., GROOTES, P., GUILDERSON, T., HAJDAS, I., HATTE, C., HEATON, T., HOFFMANN, M., HOGG, A., HUGHEN, K., KAISER, K., KROMER, B., MANNING, S., NIU, M., REIMER, R., RICHARDS, D., SCOTT, E., SOUTHON, J., STAFF, R., TURNEY, C., VAN DER PLICHT, J., 2013. INTCAL13 and MARINE13 radiocarbon age calibration curves, 0-50,000 years cal. BP. Radiocarbon, 55, 18691887. https://doi.org/10.2458/azu_js_rc.55.16947.

ŠÁlKOVÁ, T., DOHNALOVÁ, A., NOVÁK, J., HILTSCHER, T., JIŘÍK, J., VÁVRA, J., 2016. Unrecognized taphonomy as a problem of identification and the scale of contamination of archaeobotanical assemblages - the example of Prague - Zličín Migration period burial ground. Interdisciplinaria Archaeologica - Natural Sciences in Archaeology, 7(1), 87-110. https://doi.org/10.1007/s00334-014-0493-8.

ŠÁLKOVÁ, T., CHVOJKA, O., ZAVŘEL, P., 2014. Archäobotanische Untersuchungen in vorgeschichtlichen Siedlungen Südböhmens. FINES TRANSIRE, 23, 57-74.

TER BRAAK, C., SMILAUER, P., 2002. CANOCO Reference Manual and CanoDraw for Windows User's Guide: Software for Canonical Community Ordination (version 4.5). Wageningen: Biometris. 
